\title{
Professionally-oriented tasks in the formation of competencies in the field of students' research activities
}

\section{Tarefas com orientação profissional na formação de competências no campo das atividades de pesquisa dos alunos}

\section{Tareas de orientación profesional en la formación de competencias en el campo de las actividades de investigación de los estudiantes}

\author{
Yulia Alexandrovna Kireeva ${ }^{1}$ (D) \\ ${ }^{1}$ Russian State University of Tourism and Service, Moscow, Russia. \\ Corresponding author: \\ Yulia Alexandrovna Kireeva \\ Email: kireeva.y.a@bk.ru \\ How to cite: Kireeva, Y. A. (2021). Professionally-oriented tasks in the formation of competencies in the field of \\ students' research activities. Revista Tempos e Espaços em Educação, 14(33), e15252. \\ http://dx.doi.org/10.20952/revtee.v14i33.15252
}

\begin{abstract}
Due to the introduction and implementation of the requirements of the third-generation Federal State Educational Standards, the importance of students' involvement in research activities during their studies has increased. Currently, special importance in the higher education system is given to the issues related to the organization of such work with students. Having mastered the principal educational program, graduates should be ready to carry out professional activities in the field of applied research, as well as to solve various research tasks. To do this, the graduates must have a certain set of competencies, formed in various ways and methods in the course of professional training. One of the best ways to form competencies both in the field of future profession and research activities is professionally-oriented tasks. As a rule, such tasks are offered to students starting from the first year. Gradually, the level of complexity of the tasks increases, and to solve such tasks, senior-year students need knowledge across multiple disciplines. The article presents a list of academic disciplines, whose study using various forms can train and develop various competencies, including research ones. Universities regularly involve students in research work. However, at present, an appropriate pedagogically sound system of continuous involvement of students in this work is required.
\end{abstract}

Keywords: Research activities of students. Competencies. Professionally-oriented tasks. Tourism. 


\section{RESUMO}

Devido à introdução e implementação dos requisitos das Normas Educacionais Estaduais Federais de terceira geração, a importância do envolvimento dos alunos em atividades de pesquisa durante seus estudos aumentou. Atualmente, especial importância no sistema de ensino superior é dada às questões relacionadas à organização desse tipo de trabalho com os alunos. Tendo dominado o programa educacional principal, o graduado deve estar pronto para realizar atividades profissionais no campo da pesquisa aplicada, bem como para resolver várias tarefas de pesquisa. Para tanto, os graduados devem possuir um determinado conjunto de competências, formadas de diversas formas e métodos no decorrer da formação profissional. Uma das melhores maneiras de formar competências, tanto no campo da futura profissão quanto nas atividades de pesquisa, são as tarefas de orientação profissional. Via de regra, essas tarefas são oferecidas aos alunos a partir do primeiro ano. Gradualmente, o nível de complexidade das tarefas aumenta e, para resolvê-las, os alunos do último ano precisam de conhecimentos em várias disciplinas. O artigo apresenta uma lista de disciplinas acadêmicas, cujo estudo em várias formas pode treinar e desenvolver várias competências, incluindo a pesquisa uns. As universidades regularmente envolvem os alunos em trabalhos de pesquisa. No entanto, atualmente, é necessário um sistema adequado pedagogicamente sólido de envolvimento contínuo dos alunos neste trabalho.

Palavras-chave: Atividades de pesquisa de estudantes. Competências. Tarefas de orientação profissional. Turismo.

\section{RESUMEN}

Debido a la introducción e implementación de los requisitos de los Estándares Educativos del Estado Federal de tercera generación, ha aumentado la importancia de la participación de los estudiantes en las actividades de investigación durante sus estudios. Actualmente, se le da especial importancia en el sistema de educación superior a los temas relacionados con la organización de dicho trabajo con los estudiantes. Habiendo dominado el programa educativo principal, los graduados deben estar preparados para realizar actividades profesionales en el campo de la investigación aplicada, así como para resolver diversas tareas de investigación. Para ello, los egresados deben tener un determinado conjunto de competencias, formadas de diversas formas y métodos en el transcurso de la formación profesional. Una de las mejores formas de formar competencias tanto en el campo de la futura profesión como en las actividades de investigación son las tareas de orientación profesional. Como regla general, estas tareas se ofrecen a los estudiantes a partir del primer año. Gradualmente, el nivel de complejidad de las tareas aumenta, y para resolver dichas tareas, los estudiantes de último año necesitan conocimientos en múltiples disciplinas. El artículo presenta una lista de disciplinas académicas, cuyo estudio mediante diversas formas puede capacitar y desarrollar diversas competencias, incluida la investigación unos. Las universidades involucran regularmente a los estudiantes en trabajos de investigación. Sin embargo, en la actualidad, se requiere un sistema apropiado y pedagógicamente sólido de participación continua de los estudiantes en este trabajo.

Palabras clave: Actividades de investigación de los estudiantes. Competencias. Tareas de orientación professional. Turismo.

\section{INTRODUCTION}

Current trends in the development of society require universities to improve the educational process, apply innovative pedagogical technologies, increase the proportion of practice-oriented inclass learning of the disciplines of the major curriculum, expand the range of educational activities aimed at meeting the personal interests of students, as well as the development of competencies necessary for graduates.

According to the requirements of the Federal State Educational Standard of Higher Education (FSES HE), the bachelor program on Tourism (43.03.02) approved by the Order of the 
Ministry of Education and Science of the Russian Federation of June 8, 2017, No. 516, was amended accordingly in terms of structure and content of an exemplary basic educational program (EBEP). The new standard also led to changes in the conditions for implementing the program.

The implementation of the requirements of the FSES HE 3++ required universities to solve many issues, including improving educational materials, modernizing the material and technical support, using innovative teaching technologies, and improving the professional level of the academic staff. All of the above has led to qualitative changes in the training of specialists in the field of tourism and hospitality.

The FSES HE 3++ defines the following professional areas in the bachelor degree course in Tourism major (43.03.02), in which graduates who have completed the bachelor's program can carry out professional activities:

- culture and art (in the field of excursion activities);

- services to the population (trade, maintenance, repair, providing personal services, hospitality services, public catering, etc.);

- $\quad$ applied research (Federal State Educational Standard of Higher Education, n.d.).

The main types of professional activity tasks of graduates are:

- organizational and managerial;

- design;

- technological;

- service;

- researchErro! Indicador não definido.Erro! Indicador não definido. (Federal State Educational Standard of Higher Education, n.d.).

It should be noted that at present, a specialist who has mastered both professional competencies and competencies in the field of research activities is becoming more popular and demanded.

Thus, the formation of readiness of graduates for research activities is one of the most important tasks when training contemporary specialists in the tourism and hospitality sector (Zimnyaya, 2010; Kireeva, 2015). Following the requirements of the FSES HE, as well as requirements of the industry, achieving maximum efficiency of training in the tourism university requires the application of practice-oriented technologies. The development of practice-oriented tasks and their implementation in the learning process allows developing the necessary set of competencies.

\section{LITERATURE REVIEW}

The issues of organizing students' research activity and its effectiveness were considered by various authors based on different approaches. The authors, such as V.I. Zagvyazinsky, I.A. Zimnyaya, T.I. Erofeev, I.I. Ilyasov, A.V. Korzhuyev, V.V. Kraevsky, A.M. Novikov, V.A. Popkov, V.A. Slastenin, M.G. Yaroshevsky, etc.consider research activities as a means of personal development. In their scientific works, D.B. Bogoyavlenskaya, N.E. Varlamovaand V.P. Kvasha consider the problems of forming research skills.

The use of tasks in professional training is considered in different aspects. The authors, such as S.L. Rubinstein, G.A. Ball, O.K. Tikhomirov, V.V. Petukhov, A.V. Beloshistaya, A.N. Leontiev, S.Ya. Batyshev, A.M. Novikov, A.A. Verbitsky, and others,in their works,consider tasks as a practical method of training, explore their elements, and define problem-based, task-based, and contextual approaches to training.

The works of E.A. Zubkova, N.V. Skorobogatova, O.A. Sorokina, N.M. Zhukova, P.F. Kubrushko, M.V. Shingareva, N.A. Prusova, N.S. Sebryaeva, Zh.V. Komarova, V.V., Likholetova, V.P. Grakhova, Yu.G. Kislyakova, U.F. Simakova, A.Yu. Arabchikova, L.N. Vasilyeva, L.N. Troitskaya, etc. 
consider the development, selection, and application of professionally-oriented tasks depending on the fields of professional activity to implement the principle of professional orientation of training.

\section{METHODOLOGY}

When preparing this article, the following general scientific methods of theoretical research were used:

- studying and analyzing the relevant pedagogical literature on the concerned topic;

- systematizing theoretical data on the concept of "task";

- synthesizing based on a combination of the teachers' attitudes in the field of training professionals for the tourism and hospitality sector, as well as the formation of research competencies in the course of professional training.

\section{RESULTS AND DISCUSSION}

The organization of research activities of students occupies a special place in the learning process. According to the requirements of the FSES HE $3++$, both the bachelor and master must have the appropriate competencies to carry out research activities. It should be noted that within the bachelor's program, students acquire first of all basic research skills aimed at mastering the future profession, while master's program students acquire skills that are maximally focused on research and science, as well as pedagogical activities.

The research activities of students (RAS) include the academic and research work of students (ARWS) and the scientific research work of students (SRWS).

The main purpose of the ARWS is an educational result. This type of RAS aims at educating students and developing their research competencies. In turn, due to active participation in scientific research work, students receive new objective scientific knowledge.

The analysis of pedagogical literature has shown that RAS can have different types and implementation forms (Kireeva, 2015; Bordovskaya, 2011; Chuprova, 2012), as well as different degrees of attitude to the educational process (Figure 1).

Thus, the SRWS is inextricably linked with the educational processErro! Indicador não definido., as a rule, directly at the university departments and faculties, and is based on the principles indicated in table 1.

Table 1. Students' competencies forming principles in the field of research activities (Al'mukhanova, 2007; Prokhorov, 1969-1978; Ershova \& Mullina, 2015; Zimnyaya, 2004; Chuprova, 2012; Shishov \& Agapov, 2000).

\begin{tabular}{lll}
\hline No. & Principles & Characteristics of the principles \\
\hline 1 & Scientificity & $\begin{array}{l}\text { Compliance with the level of contemporary science and professional } \\
\text { education content } \\
\text { The orientation of students to future professional activities by applying } \\
\text { professionally-oriented tasks } \\
\text { Use of elective tasks that promote independent actions of students }\end{array}$ \\
3 & Variability & $\begin{array}{l}\text { Independent acquisition of knowledge, skills, and abilities } \\
\text { throughscientific research activities }\end{array}$ \\
\hline
\end{tabular}


Figure 1. The types and goals of the research activities of students (RAS) (Kireeva, 2018; Kireeva, 2020; Ozhegov, 1990; Bordovskaya, 2011).

\begin{tabular}{|c|c|c|}
\hline \multicolumn{3}{|c|}{ Types of RAS in relation to the educational process } \\
\hline$\nabla$ & $\downarrow$ & \\
\hline $\begin{array}{l}\text { RAS integrated into } \\
\text { the learning process }\end{array}$ & $\begin{array}{l}\text { RAS complementing } \\
\text { the learning process }\end{array}$ & $\begin{array}{l}\text { RAS concomitant to } \\
\text { the educational }\end{array}$ \\
\hline$\downarrow$ & $\nabla$ & $\downarrow$ \\
\hline $\begin{array}{l}\text { - Reports, presentations, } \\
\text { essays, term papers } \\
\text { (projects), final qualification } \\
\text { papers with scientific research } \\
\text { elements; } \\
\text { - Individual tasks with scientific } \\
\text { research elements completed } \\
\text { during the course of practical } \\
\text { training }\end{array}$ & $\begin{array}{l}\text { - Small research groups; } \\
\text { - Individual tasks with scientific } \\
\text { research elements under the } \\
\text { supervision of a teacher } \\
\text { (supervisor); } \\
\text { - Scientific events: scientific } \\
\text { seminars, conferences, } \\
\text { competitions, Olympiads }\end{array}$ & $\begin{array}{l}\text { - Research, } \\
\text { carried out by the } \\
\text { University within } \\
\text { the framework of } \\
\text { grants; } \\
\text { - Author's } \\
\text { scientific } \\
\text { research }\end{array}$ \\
\hline$\downarrow$ & $\downarrow$ & $\downarrow$ \\
\hline \multicolumn{3}{|c|}{$\begin{array}{l}\text { The goals of SRWS } \\
\text { - expanding and deepening students' knowledge in the field of theoretical foundations of the studied } \\
\text { disciplines, obtaining and developing certain practical skills of independent scientific research activities; } \\
\text { - conducting scientific research to solve current problems put forward by science and practice; } \\
\text { - developing the skills of competent presentation of the results of students' own scientific research and } \\
\text { the ability to defend and justify the results obtained in a reasoned manner; } \\
\text { - implementing new information technologies when conducting scientific research, providing information } \\
\text { and software subport for research. and subportina the results obtained. }\end{array}$} \\
\hline
\end{tabular}

To form and develop competencies in the field of research activities of future specialists in the tourism and hospitality sector, many universities need to rethink not only the learning content but also approaches to the learning process. This concerns especially those subjects of the training specialties, which play a major role in developing professional and research competencies. As shown by the reviews of potential employers, as well as graduates, the study of theoretical material, passing tests, and solving cases is not enough to form research competencies in future specialists in the tourism and hospitality sector. To solve this problem, the process of teaching students in special academic disciplines should include also specially designed professionally-oriented tasks that would contribute to the formation and development of students' competencies in the field of research activities. Starting from the first year, students acquire the knowledge, skills, and abilities necessary to solve professionally-oriented tasks. In the senior years, students can solve complex professionally-oriented tasks, as well as demonstrate acquired research competencies.

The analysis of pedagogical literature allowed systematizing the definitions of the term "task" (Table 2).

Table 2. Interpretation of the term "task" by various authors.

\begin{tabular}{|c|c|c|}
\hline No. & Interpretation of the term & $\begin{array}{l}\text { Author } \\
\text { or source }\end{array}$ \\
\hline 1 & $\begin{array}{l}\text { Text, containing numerical components. The structure of this text is such that it } \\
\text { allows distinguishing condition and a requirement (which is not always } \\
\text { expressed in the form of an interrogative sentence) }\end{array}$ & A.V. Beloshastaya \\
\hline 2 & A problematic situation with an explicit goal tobe achieved & O.K. Tikhomirov \\
\hline 3 & Something that requires execution, permission. & S.I. Ozhegov \\
\hline
\end{tabular}


An exercise that is performed by inference, calculation.

A complex question, a problem that requires research and resolution.

4 A problem situation which is reflected in consciousness or objectified in a signed model, containing data and conditions which are necessary and sufficient for its resolution by the available means of knowledge and experience.

5

One of the methods of teaching and testing students' knowledge and practical

skills used in all types of general and special educational institutions.

The Great Psychological Encyclopedia

The Great Soviet Encyclopedia

A professional task is a specification of the goal of professional activity, reflecting its essence in the form of lined-up stages of overcoming by the teacher the contradictions between the problem situation and the need to find solutions, understanding, and choosing ways to solve complex mathematical problems (Musina, 2004).

A professionally-oriented task is a situation modeled by a teacher during a training session, whose description corresponds to the types of professional activity, and provides all the necessary information for its solution.

The main purpose of including such professionally-oriented tasks in the process of professional training of tourism and hospitality specialists is to expand theoretical knowledge, consolidate in practice the skills and abilities required to perform the relevant employment functions, in other words, to form the necessary competencies.

Teachers, when organizing research activities of students, should take into account the principle of succession from the first year to the fourth, from one discipline of the curriculum to another. If this principle is observed, then knowledge, skills, and abilities are formed gradually, and their complexity and volume within the framework of the student's scientific work also increase gradually. Practice-oriented tasks are a perfect fit in this case.

As an example, the curriculum in the training major of Tourism (43.03.02) at the FSBEI of HE "Russian State University of Tourism and Service" was analyzed. In the course of the analysis, academic disciplines were identified, whose study was harmonized most optimally with various forms of research activities of students by solving professionally-oriented tasks (Table 3 ).

Table 3. Implementation of various forms of RAS in the framework of training major of Tourism (43.03.02) (Shishov \& Agapov, 2000).

\begin{tabular}{|c|c|c|c|}
\hline No. & $\begin{array}{l}\text { Year of } \\
\text { study }\end{array}$ & $\begin{array}{l}\text { Title of the discipline } \\
\text { according to the } \\
\text { curriculum }\end{array}$ & Forms of the RAS implementation \\
\hline 1 & 1 & $\begin{array}{l}\text { - Basics of tourism and } \\
\text { tourism activities; } \\
\text { - Service technologies in } \\
\text { tourist information } \\
\text { centers }\end{array}$ & $\begin{array}{l}\text { Reports, presentations, and reference papers. } \\
\text { For example, in the course of studying the discipline "Service } \\
\text { technologies in tourist information centers", students collect } \\
\text { material about the tourist resources of the Moscow Region. The } \\
\text { collected material is issued in the form of reports and } \\
\text { presentations. In this way, students are taught the elements of } \\
\text { research work. }\end{array}$ \\
\hline 2 & 2 & $\begin{array}{lr}\text { - Tourism } & \text { geography } \\
\text { and tourist } & \text { country } \\
\text { studies; } & \\
\text { - Tourism } & \text { resource } \\
\text { studies } & \\
\end{array}$ & $\begin{array}{l}\text { Reports, presentations, and reference papers. } \\
\text { Within these disciplines, the acquired skills of working with diverse } \\
\text { information necessary for carrying out research activities are } \\
\text { developed. }\end{array}$ \\
\hline 3 & 3 & $\begin{array}{l}\text { - Innovative } \\
\text { technologies in the } \\
\text { tourism industry; } \\
\text { - Types and trends in } \\
\text { tourism development }\end{array}$ & $\begin{array}{l}\text { Olympiads, conferences, research work competitions. } \\
\text { Within the framework of listed academic disciplines, students } \\
\text { master competencies that allow them to solve technological and } \\
\text { project types of professional tasks. In most cases, various } \\
\text { Olympiads and competitions are aimed at testing exactly these } \\
\text { competencies. }\end{array}$ \\
\hline
\end{tabular}




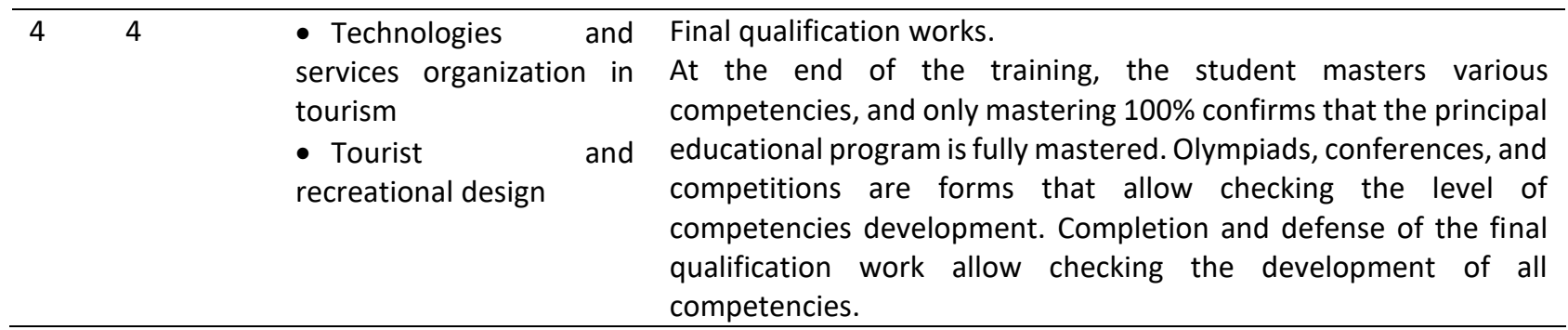

Below is an example of a professionally-oriented task aimed at developing professional and research competencies.

Students are asked to develop a program for servicing tourists participating in the conference held from September 26 to 29 in Sochi. They are asked to offer two options for the service program: individual and group. To develop a tourist service program, students need to use travel guides to Sochi.

In this case, the presented task can be attributed to the practice-oriented production tasks. In the course of implementation, the student must develop a travel itinerary, prepare a list of tourist services, select appropriate service providers, calculate the cost, as well as spread the services provided over time. Thus, to solve this problem, the student needs to conduct a little research on the opportunities of the specified city for organizing tourist services.

Teachers begin to offer similar tasks with different conditions to students of tourist universities from the junior years, forming an interest in the future profession, introducing students to basic labor functions, as well as forming professional and research competencies.

\section{CONCLUSION}

According to the introduction and implementation of the competency-based approach in education, RAS is an important and integral part of the training of qualified specialists. The involvement of students in research activities contributes to the development of professional competencies, effectively contributes to the formation of readiness and ability to solve independently professional and scientific problems of various levels. By taking part in research activities, students master the scientific research methods and acquire initial research experience; future specialists become ready for creative implementation of the knowledge acquired at the university.

\section{REFERENCES}

Al'mukhanova, A.B. (2007). Bol'shaya psihologicheskaya enciklopediya [The Great Psychological Encyclopedia]. Moscow: Eksmo.

Araujo, A., \& Silva, I. P. (2020). Maker culture and educational robotics in physics teaching: developing an automated traffic light in high school. Journal of Research and Knowledge Spreading, 1(1), e11654.

Bordovskaya, N.B. (2011). Sovremennye obrazovatel'nye tekhnologii: ucheb. Posobie [Modern educational technologies: Textbook]. Moscow: KNORUS.

Chuprova, L.V. (2012). Sistemnoe stanovlenie tvorcheskoj lichnosti budushchego specialista v obrazovatel'nom processe vuza [System-based formation of the creative personality of the future specialist in the educational process of the university]. Bulletin of the Magnitogorsk State Technical University named after G.I. Nosov, 3, 82-85.

Ershova, O. V., Mullina, E.R. (2015). Kompetentnostnyj podhod kak uslovie povysheniya kachestva podgotovki studentov [Competency-based approach as a condition for improving the quality of student training]. Science Vector of Tolyatti State University. Series: pedagogy, psychology, 1, 134-137.

Federal State Educational Standard of Higher Education: Bachelor's degree in the field of Tourism (43.03.02) major. (2016). Retrieved from: http://fgosvo.ru/news/3/1648 
Kireeva, Yu.A. (2015). Organizaciya nauchno-issledovatel'skoj raboty studentov na kafedre turoperejtinga RMAT [Organization of scientific research work of students at the Department of tour management of the RIAT]. Bulletin of the Russian International Academy for Tourism (RIAT), 1, 93-94.

Kireeva, Yu.A. (2018). Motivaciya studentov turistskogo vuza k nauchno-issledovatel'skoj deyatel'nosti [Motivation of tourist university students to research activities]. In: Kal'ney V. A. (ed.) Proceedings of the International scientific and practical Internet conference "Innovation in modern professional education". Moscow: University Book.

Kireeva, Yu.A. (2020). Nauchno-issledovatel'skaya deyatel'nost' studentov v turistskom vuze kak vazhnejshij komponent professional'noj podgotovki: soderzhatel'nyj i podgotovitel'nyj aspect [Organization of scientific research work of students at the Department of tour management of the RIAT]. In: Proceedings of the 20th International science-to-practice conference "Business strategies for tourism and hospitality in the global digital economy". Moscow: Peoples' Friendship University of Russia.

Musina, E.M. (2004). Professional'no-orientirovannye problemnye zadachi po ekonomike dlya studentov tekhnicheskih special'nostej srednego professional'nogo obrazovaniya: Ph.D. thesis in pedagogy [Professionallyoriented problem-basedtasks in economics for students of technical majors of secondary vocational education]. Moscow: Moscow State Agroengineering University named after V.P. Goryachkina.

Oliveira, A. M., Gerevini, A. M., \& Strohschoen, A. A. G. (2017). Diário de bordo: uma ferramenta metodológica para o desenvolvimento da alfabetização científica. Revista Tempos E Espaços Em Educação, 10(22), 119-132.

Ozhegov, S.I. (1990). Tolkovyj slovar' russkogo yazyka [Explanatory Dictionary of the Russian Language]. Retrieved from: http://www.ozhegov.org

Prokhorov, A.M. (1969-1978). Bol'shaya sovetskaya enciklopediya [The Great Soviet Encyclopedia]. Vol. 5. Moscow: Sovetskaya Enciklopediya.

Rodrigues, B. M., Santos, J. E. B., \& Vasconcelos, C. A. (2020). Conceptions of undergraduate students in Chemistry on the use of interactive interfaces in and for the activities developed in the distance course. Journal of Research and Knowledge Spreading, 1(1), e11649.

Santos, J. E. B. (2020). Cartographic narratives: the teaching of mathematics and ICT. Journal of Research and Knowledge Spreading, 1(1), e11645.

Shishov, S.G., Agapov, I.V. (2000). Kompetentnostnyj podhod k obrazovaniyu: prihot' ili neobhodimost' [Competencebased approach to education: A whim or necessity]. Standards and Monitoring in Education, 2, 58.

Zimnyaya, I.A. (2004). Kompetentnost' cheloveka novoe kachestvo rezul'tata obrazovaniya [Human competence asa new quality of education]. In: Problems of Education Quality: Materials of the XIII All-Russian meeting. Moscow: Research Center for the Problems of the Quality of Training of Specialists.

Zimnyaya, I.A. (2010). Issledovatel'skaya deyatel'nost' v vuzovskoj i poslevuzovskoj podgotovke bakalavrov, magistrov, aspirantov: A collection of articles [Research activities in university and post-university training of bachelors, masters, and post-graduates]. Moscow: Research Center for Quality Problems in Training Specialists.

Received: 4 January 2021 | Accepted: 1 February 2021 | Published: 16 February 2021

This is an Open Access article distributed under the terms of the Creative Commons Attribution License, which permits unrestricted use, distribution, and reproduction in any medium, provided the original work is properly cited. 